\title{
Pengaruh Pemasangan Poster Anjuran Buang Sampah terhadap Pemanfaatan Tempat Sampah di Tempat Wisata
}

\author{
Nining Prastiwi ${ }^{*}$, Zahroh Shaluhiyah ${ }^{* *)}$, Farid Agushybana ${ }^{* *)}$ \\ *) Stikes Kusuma Husada Surakarta \\ ${ }^{* *}$ Fakultas Kesehatan Masyarakat Universitas Diponegoro \\ Korespondensi: niningprastiwi41@gmail.com
}

\begin{abstract}
Background: Cleanliness of tourist area is managers and visitors responsibilities to maintain the beauty of tourist destinations. Disposing of trash in its place becomes very important in maintaining the cleanliness of tourist sites. The role of health promotion media to improve awareness and behavior of tourist in maintaining cleanliness is necessary to be conducted. The purpose of this study was to analyze the effect of providing garbage disposal posters towards the utilising trash bin in tourist sites.
\end{abstract}

Method: This study employs a quantitative method with a quasy experimental approach, non randomized control group pretest posttest design. It was carried out in four tourist sites which consist of two tourist sites as intervention area and the others as control. Sample of this study was consisted of 15 bins/each site which met the criteria of sanitation standards and selected purposively so that the total sample was 30 bins in the intervention and 30 bins in the control areas. The variables included the volume of waste in each trash bin, the quality of trash bin distributed and the number of visitors before and after intervention. Measurements were conducted for 14 days.

Results: The volume of waste was increased significantly after providing posters in the intervention sites compared to controls'. Likewise, the quality of trash bin distributed at tourist sites was also increased significantly in the intervention areas compared to controls. The number of visitors at four destinations was increased significantly after intervention because post-test was conducted at long vacation period. That would directly effect to waste volume in the trash bin at 4 tourist destinations. This study recommends to managers to put interesting poster or other instagramable media to promote healthy behaviour related to the cleanliness and beauty at tourist areas.

Keywords: tourism, healthy behaviour, poster, trash bin, visitor

\section{PENDAHULUAN}

Pariwisata berkembang dengan pesat seiring terjadinya kecenderungan penduduk yang semakin memerlukan hiburan dengan menjelajahi tempat baru dan mendapatkan suasana dan perjalanan baru. Ciri dari berkembangnya pariwisata di suatu negara adalah banyaknya wisatawan asing yang masuk dan berkunjung ke negara tersebut. Dengan adanya wisatawan asing tersebut, maka terjadi pembangunan sarana dan prasarana yang semakin lengkap di tempat pariwisata dengan tujuan memberikan kenyamanan wisatawan yang berkunjung. ${ }^{(1)}$ Secara nasional jumlah kunjungan wisata mancanegara di Indonesia di bulan JanuariNovember 2015 mencapai 8,7 juta jiwa, dan mengalami pertumbuhan positif sebesar 3,2\% dibandingkan periode yang sama pada tahun 2014 (2) $^{(2)}$ 
Pariwisata merupakan sektor yang kelangsungan hidupnya sangat ditentukan oleh baik buruknya kondisi lingkungan. Selain itu, sektor pariwisata sangat rentan terhadap kerusakan lingkungan, misalnya pencemaran oleh limbah domestik, penumpukan sampah, dan kerusakan yang disebabkan oleh aktivitas manusia. Menyadari pentingnya keamanan dan keselamatan wisatawan, maka muncul gagasan dari World Tourism Organization (WTO) untuk memberikan kebijakankebijakan di industri pariwisata. Keamanan dan keselamatan pengunjung tempat wisata bukan saja menjadi tanggung jawab pemilik atau pengelola tempat wisata, tetapi juga bagian tanggung jawab Pemerintah Daerah maupun pusat (stakeholder). ${ }^{(3)}$

Sampah adalah sesuatu yang tidak dipakai, tidak disenangi atau segala sesuatu yang harus dibuang yang berasal dari semua kegiatan manusia yang berwujud baik berupa zat organik maupun anorganik, yang bersifat terurai maupun tidak dapat terurai serta tidak berguna lagi sehingga dibuang ke lingkungan. ${ }^{(4)}$ Keberadaan sampah sangat tidak diinginkan apabila dihubungkan dengan faktor kesehatan, kebersihan, keindahan dan kenyamanan. Penanganan masalah sampah di area tempat wisata merupakan masalah yang rumit dan masih banyak mengalami kendala karena kurangnya pengertian wisatawan selaku pengunjung tempat wisata terhadap dampak yang dapat ditimbulkan dari sampah. Faktor yang menyebabkan permasalahan sampah ini adalah partisipasi wisatawan yang kurang memelihara kebersihan dan kebiasaan membuang sampah sembarangan atau tidak pada tempatnya. Akibatnya banyak sampah yang menumpuk dan berserakan di area tempat wisata. Hal tersebut dapat menurunkan citra dari suatu tempat wisata. ${ }^{(5)}$

Provinsi Jawa Tengah merupakan salah satu daerah tujuan wisata yang mempunyai sekitar 245 obyek yang terdiri dari 97 tempat wisata alam, 86 obyek buatan dan 62 lokasi pelancongan budaya. Tetapi jumlah wisatawan yang berkunjung semakin menurun jumlahnya. Akhir tahun 2016, total kunjungan wisatawan di Jawa Tengah mengalami penurunan sebesar $2,9 \%$, yaitu dari 15.759 .444 orang pada tahun 2015 yang terdiri atas 15.455.546 wisatawan domestik dan 303.898 wisatawan mancanegara menjadi 15.314.118 orang di tahun 2016. ${ }^{(6)}$ Penurunan tersebut disebabkan adanya isu gangguan keamanan, lemahnya pengelolaan industri kepariwisataan dan kondisi lingkungan di area tempat wisata yang kotor dan kurang terurus. Selain itu, belum memadainya fasilitas pendukung untuk kenyamanan pengunjung juga menjadi alasan turunnya kunjungan wisatawan. ${ }^{(7)}$

Peraturan Daerah Kota Semarang No 3 Tahun 2010 tentang pariwisata di Kota 
Semarang menyatakan bahwa jumlah kunjungan wisatawan dipengaruhi oleh faktor internal dan eksternal. Kunjungan wisatawan nusantara di Kebun Binatang Mangkang pada tahun 2015 sebanyak 361.965 jiwa dengan total pendapatan mencapai Rp. 2.800.653.756,-. Sedangkan jumlah kunjungan wisatawan nusantara untuk Pantai Marina sebanyak 468.890 dan untuk kunjungan wisatawan mancanegara sebanyak 36 dengan jumlah pendapatan Rp. 1.759.498.000,-. ${ }^{(8)}$ Tingkat kunjungan masyarakat ke Kebun Binatang Mangkang dan Pantai Marina masih sangat rendah. Kehadiran sampah menjadi salah satu persoalan yang dihadapi oleh pemilik maupun pengelola tempat wisata. Kurangnya kesadaran wisatawan tentang arti penting pelestarian lingkungan di area tempat wisata menjadi salah satu faktor yang paling utama banyaknya sampah di area tempat wisata. ${ }^{(7)}$

Upaya meningkatkan kesadaran masyarakat yang berkunjung untuk memanfaatkan tempat sampah sangatlah penting, dengan tujuan agar para pengunjung merasa nyaman, bersih, indah puas, terjamin kesehatannya dan ingin kembali lagi berkunjung ke tempat wisata tersebut. Oleh karena itu diperlukan upaya agar pengunjung dapat membuang sampah pada tempat yang telah disediakan dengan memberikan promosi kesehatan melalui poster yang diletakkan di dekat tempat sampah sehingga diharapkan dapat meningkatkan kesadaran pengunjung untuk menjaga kebersihan dan kerapihan tempat wisata Kota Semarang. Tujuan penelitian ini adalah untuk menganalisis pengaruh pemberian promosi kesehatan berupa poster di dekat tempat sampah terhadap pemanfaatan tempat sampah di tempat wisata Kota Semarang.

\section{METODE}

Penelitian ini menggunakan metode kuantitatif quasy experimental dengan rancangan non randomized control group pretest and posttest design. Pada rancangan penelitian ini, subjek dibagi menjadi dua kelompok yaitu kelompok eksperimen dan kelompok kontrol yang diharapkan kedua kelompok ini mempunyai karakteristik yang relatif sama.

Penelitian ini dilakukan pada 4 tempat wisata yaitu Kebun Binatang Mangkang dan Pantai Marina sebagai kelompok eksperimen dan tempat wisata Goa Kreo dan Pantai Baruna sebagai kelompok kontrol. Sampel tempat wisata untuk kelompok eksperimen dipilih secara purposif dengan melihat kemiripan dari tempat wisata intervensi dan kontrol seperti Pantai Marina sebagai obyek intervensi sedangkan Pantai Baruna sebagai kontrol. Demikian juga, tempat wisata Kebun Binatang Mangkang dijadikan obyek intervensi dan Goa kreo sebagai kelompok 
kontrolnya. Sedangkan tempat sampah dipilih sebagai sampel secara total sampling dengan kriteria kondisinya sesuai dengan standar kelayakan sebagai tempat sampah. Sehingga diperoleh jumlah tempat sampah yang diukur sebanyak 15 tempat sampah di masing-masing tempat wisata. Total tempat sampah penelitian menjadi sebanyak 60 buah. Selain itu sebanyak 200 pengunjung dipilih secara insidental di masing-masing tempat wisata dengan diberikan daftar tilik tentang poster yang telah dipasang saat intervensi, untuk mengetahui ketertarikan pengunjung terhadap poster yang dipasang mulai dari melihat, memperhatikan, ketertarikan dan membaca serta memahami anjuran yang ada di poster tersebut dan memanfaatkannya dalam membuang sampah. Terdapat 10 poster besar berukuran $0,7 \times 1 \mathrm{~m}$ yang dibuat berisi himbauan tentang buang sampah pada tempatnya sesuai dengan tempat wisata dan dirancang menarik untuk difoto oleh pengunjung di dua tempat wisata intervensi. Demikian juga seluruh tempat sampah yang dijadikan sampel di daerah intervensi diberikan tulisan anjuran untuk membuang sampah dengan kalimat menarik.

\section{HASIL DAN PEMBAHASAN}

Tabel 1 menunjukkan gambaran umum situasi dan kondisi jenis tempat sampah yang terdapat di keempat tempat wisata Kota Semarang. Keempatnya memiliki karakteristik yang relatif sama yaitu semuanya mempunyai tempat sampah yang terbuat dari bahan fiber dengan kapasitas volume sampah sekitar 40-50 liter. Di tempat wisata Kebun Binatang Mangkang memiliki jumlah tempat sampah sebanyak 44 unit yang dibedakan menjadi sampah organik dan nonorganik berdasarkan warnanya. Selain itu terdapat tempat sampah yang berasal dari bahan anyaman bambu atau keranjang yang tidak sesuai standard, karena tidak memiliki tutup dan terbuat dari anyaman yang tidak rapat mengakibatkan munculnya sampah dan bau menyengat. Sedangkan jumlah tempat sampah di Goa Kreo sebanyak 46 unit dengan bahan drum, karena jika disediakan tempat sampah dari fiber mudah dirusak oleh kera. Demikian pula Pantai Marina mempunyai jumlah tempat sampah sebanyak 30 unit dan Pantai Baruna sebanyak 24 unit yang terbuat dari seng atau drum bekas air atau minyak yang tidak memiliki tutup, mudah berkarat, sangat berat jika diangkat dan tidak membuat pengunjung tertarik untuk membuang sampah pada tempatnya. Sehingga dari keempat tempat wisata tersebut total tempat sampah yang diambil untuk dijadikan subyek penelitian sebanyak 60 tempat sampah dan sisanya tidak dimasukkan sebagai sampel karena tidak memenuhi kriteria. Bila dilihat dari jumlah dan 
kualitas tempat sampah di tempat wisata intervensi maupun kontrol, terlihat homogen baik jumlah maupun kualitasnya. Seperti tempat sampah di Kebun Binatang sebagai area intervensi berjumlah 44 unit dan kualitasnya terbuat dari fiber dan drum seng dibandingkan dengan tempat wisata Goa Kreo sebagai kontrol, yang berjumlah 46 buah dan terbuat dari bahan yang sama. Demikian juga tempat wisata Pantai Marina (sebagai intervensi) mempunyai jumlah tempat sampah sebanyak 30 unit dan Pantai Baruna mempunyai tempat sampah sejumlah 24 unit dengan kualitas terbuat dari fiber dan drum seng di kedua tempat wisata tersebut.

Untuk jumlah volume sampah di keempat tempat wisata sebelum diberikan intervensi memiliki jumlah yang berbedabeda. Hal ini selain karena luas tempat wisata dan jumlah pengunjung yang berbeda juga dipengaruhi oleh banyaknya pengunjung di masing-masing tempat wisata, sehingga mempengaruhi jumlah sampah yang berada di dalam maupun di luar tempat sampah sekitar area wisata. Demikian juga karena jumlah pengunjung yang berbeda membuat yang membuang sampah sembarangan menjadi berbeda pula jumlahnya. Kebanyakan sampah bertebaran di dekat tempat yang banyak pengunjung terutama di dekat penjual makanan. Di Kebun Binatang Mangkang jumlah volume sampah yang dihasilkan sebanyak 58,53 kg, di Pantai Marina sebanyak 52,03 kg, Goa Kreo sebanyak 47,15 kg, dan Pantai Baruna sebanyak 37,06 kg per minggu. Sampah yang dihasilkan berupa tempurung kelapa, bungkus makanan, plastik botol minuman dan sisa makanan. Demikian juga banyak sampah-sampah yang berserakan di jalan dan tidak dibuang pada tempatnya berasal dari sampah pengunjung yang membawa bekal dari rumah kemudian dimakan bersama dan membuang sisa makanannya di sekitar tempat wisata.

Tabel 1. Gambaran keadaan tempat sampah di ke empat lokasi wisata sebelum intervensi

\begin{tabular}{|c|c|c|c|c|}
\hline Keadaan tempat sampah & $\begin{array}{l}\text { Kebun Binatang } \\
\text { Mangkang }\end{array}$ & $\begin{array}{l}\text { Pantai } \\
\text { Marina }\end{array}$ & Goa Kreo & $\begin{array}{l}\text { Pantai } \\
\text { Baruna }\end{array}$ \\
\hline Jenis tempat sampah & $\begin{array}{l}\text { Fiber dan drum } \\
\text { seng }\end{array}$ & $\begin{array}{l}\text { Fiber dan } \\
\text { drum seng }\end{array}$ & $\begin{array}{l}\text { Fiber dan } \\
\text { drum seng }\end{array}$ & $\begin{array}{l}\text { Fiber dan } \\
\text { drum seng }\end{array}$ \\
\hline Jumlah tempat sampah & 44 unit & 30 unit & 46 unit & 24 unit \\
\hline $\begin{array}{l}\text { Jumlah sampah (rata-rata } \\
\text { dalam seminggu) }\end{array}$ & $58,53 \mathrm{~kg}$ & $52,03 \mathrm{~kg}$ & $47,15 \mathrm{~kg}$ & $37,06 \mathrm{~kg}$ \\
\hline $\begin{array}{l}\text { Peletakkan tempat } \\
\text { sampah }\end{array}$ & $\begin{array}{l}\text { Dekat dan } \\
\text { mudah diakses } \\
\text { pengunjung }\end{array}$ & $\begin{array}{l}\text { Dekat dan } \\
\text { mudah } \\
\text { diakses } \\
\text { pengunjung }\end{array}$ & $\begin{array}{l}\text { Dekat dan } \\
\text { mudah } \\
\text { diakses } \\
\text { pengunjung }\end{array}$ & $\begin{array}{l}\text { Dekat dan } \\
\text { mudah } \\
\text { diakses } \\
\text { pengunjung }\end{array}$ \\
\hline $\begin{array}{l}\text { Keberadaan poster buang } \\
\text { sampah }\end{array}$ & Tersedia & $\begin{array}{l}\text { Tidak } \\
\text { tersedia }\end{array}$ & $\begin{array}{l}\text { Tidak } \\
\text { tersedia }\end{array}$ & $\begin{array}{l}\text { Tidak } \\
\text { tersedia }\end{array}$ \\
\hline
\end{tabular}


Kurangnya peringatan yang disampaikan pengelola kepada pengunjung untuk membuang sampah di tempat yang disediakan, membuat banyak pengunjung yang tidak disiplin dalam menjaga kebersihan dan kenyamanan tempat wisata.

Tempat sampah di keempat tempat wisata diletakkan dekat dengan akses pengunjung, seperti di sekitar mushola, toilet, gazebo dan sekitar jalan sehingga mempermudah akses pengunjung dalam membuang sampah. Hal ini ditujukan untuk memberikan kemudahan kepada pengunjung untuk membuang sampah pada tempat yang telah disediakan. Akan tetapi, peletakan tempat sampah ini tidak diikuti dengan poster peringatan kepada masyarakat pengunjung. Keberadaan poster sebelum dilakukan penelitian hanya terdapat di Kebun Binatang yang dibuat oleh petugas setempat. Peringatan tentang pembuangan sampah memiliki ukuran yang kecil sehingga kurang terlihat oleh pengunjung dan tidak menarik untuk diperhatikan. Sedangkan di Pantai Marina, Goa Kreo dan Pantai Baruna, ketiganya tidak memiliki poster anjuran atau peringatan untuk membuang sampah pada tempatnya.

Tabel 2 menggambarkan respon pengunjung terhadap poster yang dipasang di dekat tempat sampah di tempat wisata intervensi. Secara umum tidak ada perbedaan respon pengunjung terhadap poster yang dipasang di kedua tempat tersebut. Sebagian besar pengunjung mengetahui adanya perbedaan di tempat wisata setelah intervensi (68-69\%), membaca poster $(74-81 \%)$ serta tulisan dan warna poster menarik (83-86\%). Sebagian besar responden merasa pemasangan poster di dekat tempat sampah merupakan hal yang tepat (85-86\%). Lebih dari separuh berpendapat cukup baik untuk ukuran poster yang dapat dijadikan tempat melakukan swafoto. Separuh pengunjung berfoto di depan poster yang menurut mereka cukup instagramable. Hampir semua pengunjung memahami isi pesan dari poster tersebut (91-93\%) dan sebagian besar pengunjung mengatakan telah mengikuti anjuran membuang sampah di tempat sampah yang disediakan (90-93\%) karena membaca dan melihat isi poster. Pemasangan poster anjuran menjadi sangat penting untuk membuat masyarakat disiplin dalam hal kebersihan lingkungan. ${ }^{(9)}$

Tabel 3 menunjukkan pemanfaatan tempat sampah melalui pengukuran volume sampah sebelum dan sesudah dipasangkan poster. Volume sampah tergantung dari jumlah sampah yang dihasilkan oleh pengunjung saat berada di tempat wisata, sehingga besar kecilnya volume sampah selain karena pemanfaatannya yang tinggi dari tempat sampah tersebut, juga karena banyak sampah yang dibuang dari jumlah pengunjung yang menghasilkan sampah. 
Tabel 2. Respon pengunjung tempat wisata terhadap poster yang dipasang di tempat wisata intervensi

\begin{tabular}{|c|c|c|c|c|c|c|c|c|}
\hline \multirow{3}{*}{ Pertanyaan } & \multicolumn{4}{|c|}{ Kebun Binatang } & \multicolumn{4}{|c|}{ Pantai Marina } \\
\hline & \multicolumn{2}{|c|}{$\mathrm{Ya}$} & \multicolumn{2}{|c|}{ Tidak } & \multicolumn{2}{|c|}{$\mathrm{Ya}$} & \multicolumn{2}{|c|}{ Tidak } \\
\hline & $\mathrm{f}$ & $\%$ & $\mathrm{f}$ & $\%$ & $\mathrm{f}$ & $\%$ & $\mathrm{f}$ & $\%$ \\
\hline $\begin{array}{l}\text { Mengetahui ada } \\
\text { perbedaan di tempat } \\
\text { wisata }\end{array}$ & 68 & 68 & 32 & 32 & 69 & 69 & 31 & 31 \\
\hline $\begin{array}{l}\text { Mengetahui letak poster } \\
\text { tentang pembuangan } \\
\text { sampah }\end{array}$ & 93 & 93 & 7 & 7 & 92 & 92 & 8 & 8 \\
\hline $\begin{array}{l}\text { Membaca poster } \\
\text { pembuangan sampah } \\
\text { yang ada di tempat } \\
\text { wisata }\end{array}$ & 74 & 74 & 26 & 26 & 81 & 81 & 19 & 19 \\
\hline $\begin{array}{l}\text { Desain tulisan dan } \\
\text { warna poster menarik }\end{array}$ & 86 & 86 & 14 & 14 & 83 & 83 & 17 & 17 \\
\hline $\begin{array}{l}\text { Lokasi peletakkan } \\
\text { poster tentang } \\
\text { pembuangan sampah } \\
\text { sudah tepat dan sesuai } \\
\text { dengan sasaran }\end{array}$ & 85 & 85 & 15 & 15 & 86 & 86 & 14 & 14 \\
\hline $\begin{array}{l}\text { Ukuran poster tentang } \\
\text { pembuangan sampah } \\
\text { sudah tepat }\end{array}$ & 63 & 63 & 37 & 37 & 64 & 64 & 36 & 36 \\
\hline $\begin{array}{l}\text { Berfoto di semua } \\
\text { tempat poster } \\
\text { diletakkan }\end{array}$ & 53 & 53 & 47 & 47 & 46 & 46 & 54 & 54 \\
\hline $\begin{array}{l}\text { Mengerti dan paham } \\
\text { tentang pesan poster }\end{array}$ & 93 & 93 & 7 & 7 & 91 & 91 & 9 & 9 \\
\hline $\begin{array}{l}\text { Berkeinginan untuk } \\
\text { memanfaatkan tempat } \\
\text { sampah yang telah } \\
\text { disediakan di tempat } \\
\text { wisata setelah melihat } \\
\text { poster }\end{array}$ & 88 & 88 & 12 & 12 & 88 & 88 & 12 & 12 \\
\hline $\begin{array}{l}\text { Mau membuang } \\
\text { sampah pada tempatnya } \\
\text { setelah melihat poster }\end{array}$ & 90 & 90 & 10 & 10 & 93 & 93 & 7 & 7 \\
\hline
\end{tabular}

Volume sampah rata-rata per hari di Kebun Binatang sebanyak 4,2 kg/hari, paling banyak dibanding dengan tempat wisata lainnya. Begitu juga setelah diberikan intervensi poster, volumenya bertambah lebih banyak $(6,6 \mathrm{~kg} / \mathrm{hari})$ hanya sedikit lebih tinggi dibandingkan Pantai
Marina. Volume sampah di Pantai Marina juga lebih banyak setelah diintervensi (dari rata-rata $3,7 \mathrm{~kg}$ sebelum intervensi menjadi $6,6 \mathrm{~kg}$ sesudah intervensi). Hal ini terjadi karena selain jumlah pengunjungnya lebih banyak, juga waktu pengukuran di keempat tempat wisata bertepatan dengan masa libur 
panjang sehingga jumlah pengunjung meningkat. Pada tempat wisata Goa Kreo dan pantai Baruna, volume sampah di kedua tempat wisata tersebut relatif tetap, walaupun juga terjadi sedikit kenaikan. Di Goa Kreo, sampah meningkat dari $3,3 \mathrm{~kg}$ menjadi 4,5 kg. Sedangkan sampah di Pantai Baruna meningkat dari $2,6 \mathrm{~kg}$ menjadi 3,0 kg. Terdapat perbedaan volume sampah di dalam tempat sampah yang signifikan secara statistik pada kedua tempat wisata yang diberikan intervensi poster dengan p-value $<0,05$ baik di Kebun Binatang maupun di Pantai Marina dengan $p$-value $=0,001$. Hal ini sesuai dengan penelitian terdahulu yang menyatakan bahwa meningkatnya jumlah timbunan sampah di tempat wisata bekas Pelabuhan Buleleng Bali dipengaruhi banyaknya pengunjung yang membuang sampah di tempat sampah di sekitar lokasi tempat wisata. ${ }^{(10)}$

Hasil penelitian menunjukkan bahwa nilai tempat sampah sebelum dan sesudah intervensi menunjukkan perbedaan yang signifikan $(p$-value $<0,05)$ di daerah intervensi yaitu di Kebun Binatang dan Pantai Marina. Sedangkan di daerah kontrol tidak terjadi perbedaan yang bermakna $(p$ value $>0,05)$.

Hal ini terjadi di daerah intervensi, karena pengelola ikut berinisiatif memperbaiki ketersediaan tempat sampah yang layak dan terstandar untuk sanitasi lingkungan wisata setelah diberikan himbauan melalui poster, sehingga lebih banyak tempat sampah dengan kualitas lebih baik disediakan di daerah intervensi. Sedangkan untuk daerah kontrol tidak terjadi perubahan kualitas tempat sampah.

Tabel 3. Besaran volume sampah sebelum dan sesudah intervensi di empat tempat wisata

\begin{tabular}{cccccccc}
\hline Tempat Wisata & Mean & Median & $\begin{array}{c}\text { Standar } \\
\text { deviasi }\end{array}$ & $\begin{array}{c}\text { Total } \\
\text { volume } \\
\text { sampah }\end{array}$ & Min & Max & $\begin{array}{c}p \text { - } \\
\text { value }\end{array}$ \\
\hline $\begin{array}{c}\text { Kebun Binatang } \\
\text { Sebelum }\end{array}$ & 4,2021 & 3,9850 & 0,72539 & $58,53 \mathrm{~kg}$ & $1,37 \mathrm{Kg}$ & $5,45 \mathrm{~kg}$ & 0,000 \\
$\quad \begin{array}{l}\text { Sesudah } \\
\text { Pantai Marina }\end{array}$ & 6,6129 & 6,5750 & 1,18796 & $92,58 \mathrm{~kg}$ & $4,71 \mathrm{~kg}$ & $8,46 \mathrm{~kg}$ & \\
$\quad$ Sebelum & 3,7164 & 3,1450 & 0,95697 & $52,03 \mathrm{~kg}$ & $2,82 \mathrm{~kg}$ & $5,33 \mathrm{~kg}$ & 0,001 \\
$\quad$ Sesudah & 6,6093 & 6,4800 & 1,20322 & $92,53 \mathrm{~kg}$ & $4,88 \mathrm{~kg}$ & $8,33 \mathrm{~kg}$ & \\
Goa Kreo & & & & & & & \\
$\quad$ Sebelum & 3,3679 & 2,9150 & 0,88573 & $47,15 \mathrm{~kg}$ & $2,28 \mathrm{~kg}$ & $4,74 \mathrm{~kg}$ & 0,516 \\
$\quad$ Sesudah & 4,5921 & 4,5200 & 0,70937 & $64,29 \mathrm{~kg}$ & $3,51 \mathrm{~kg}$ & $5,85 \mathrm{~kg}$ & \\
$\begin{array}{c}\text { Pantai Baruna } \\
\quad \text { Sebelum }\end{array}$ & 2,6471 & 2,5300 & 0,44420 & $37,06 \mathrm{~kg}$ & $2,16 \mathrm{~kg}$ & $3,69 \mathrm{~kg}$ & 0,735 \\
$\quad$ Sesudah & 3,0593 & 3,0200 & 0,27342 & $42,48 \mathrm{~kg}$ & $2,75 \mathrm{~kg}$ & $3,70 \mathrm{~kg}$ & \\
\hline
\end{tabular}


Tabel 4. Penilaian tempat sampah sebelum dan sesudah intervensi di empat tempat wisata

\begin{tabular}{|c|c|c|c|c|c|c|c|c|}
\hline \multirow[t]{3}{*}{ Tempat Wisata } & \multirow[t]{3}{*}{ Mean } & \multirow[t]{3}{*}{ Median } & \multirow{3}{*}{$\begin{array}{l}\text { Standar } \\
\text { deviasi }\end{array}$} & \multicolumn{4}{|c|}{ Kategori } & \multirow{3}{*}{$\begin{array}{c}p- \\
\text { value }\end{array}$} \\
\hline & & & & \multicolumn{2}{|c|}{ Baik } & \multicolumn{2}{|c|}{ Buruk } & \\
\hline & & & & f & $\%$ & $\mathrm{f}$ & $\%$ & \\
\hline \multicolumn{9}{|l|}{ Kebun Binatang } \\
\hline Sebelum & 7,00 & 7,00 & 1,177 & 13 & 86,66 & 2 & 13,33 & \multirow{2}{*}{0,01} \\
\hline Sesudah & 7,86 & 8,00 & 0,747 & 15 & 100 & 0 & 0 & \\
\hline \multicolumn{9}{|l|}{ Pantai Marina } \\
\hline Sebelum & 6,71 & 7,00 & 1,069 & 13 & 86,66 & 2 & 13,33 & \multirow{2}{*}{0,001} \\
\hline Sesudah & 7,86 & 8,00 & 0,770 & 15 & 100 & 0 & 0 & \\
\hline \multicolumn{9}{|l|}{ Goa Kreo } \\
\hline Sebelum & 7,14 & 7,00 & 1,099 & 13 & 86,66 & 2 & 13,33 & \multirow{2}{*}{1,00} \\
\hline Sesudah & 7,14 & 7,00 & 1,099 & 13 & 86,66 & 2 & 13,33 & \\
\hline \multicolumn{9}{|l|}{ Pantai Baruna } \\
\hline Sebelum & 6,86 & 7,00 & 1,027 & 13 & 86,66 & 2 & 13,33 & \multirow{2}{*}{0,655} \\
\hline Sesudah & 6,86 & 7,00 & 1,027 & 13 & 86,66 & 2 & 13,33 & \\
\hline
\end{tabular}

Tabel 5. Jumlah pengunjung sebelum dan sesudah intervensi di keempat tempat wisata

\begin{tabular}{lccrrrrr}
\hline Tempat wisata & Mean & Median & $\begin{array}{c}\text { SD } \\
\text { deviasi }\end{array}$ & $\begin{array}{c}\text { Total } \\
\text { pengunjung }\end{array}$ & Min & Max & p-value \\
\hline Kebun Binatang & & & & & & & \\
$\quad$ Sebelum & 362,93 & 360,50 & 102,124 & 5.081 & 221 & 521 & 0,000 \\
$\quad$ Sesudah & 545,07 & 526,50 & 82,251 & 7.631 & 451 & 690 & \\
Pantai Marina & & & & & & & \\
$\quad$ Sebelum & 407,07 & 389,00 & 95,057 & 5.699 & 287 & 572 & 0,000 \\
$\quad$ Sesudah & 504,71 & 479,00 & 91,033 & 7.066 & 386 & 672 & \\
Goa Kreo & & & & & & & \\
$\quad$ Sebelum & 376,29 & 365,50 & 72,831 & 5.268 & 279 & 479 & 0,000 \\
$\quad$ Sesudah & 493,29 & 506,50 & 89,303 & 6.891 & 351 & 603 & \\
Pantai Baruna & & & & & & & \\
$\quad$ Sebelum & 191,29 & 187,50 & 33,600 & 2.678 & 122 & 250 & 0,020 \\
$\quad$ Sesudah & 213,21 & 227,50 & 45,804 & 2.985 & 122 & 264 & 0,020 \\
\hline
\end{tabular}

Tabel 5 memperlihatkan jumlah pengunjung sebelum dan sesudah intervensi di keempat tempat wisata. Terdapat peningkatan jumlah pengunjung yang signifikan sebelum dan sesudah intervensi di keempat tempat wisata dengan $p$-value $<0,05$. Peningkatan pengunjung yang tertinggi berada pada tempat wisata Kebun Binatang yaitu sebesar 2.550 pengunjung. Pengunjung di tempat wisata ini datang dari seluruh daerah di Provinsi Jawa, dan paling banyak berasal dari daerah-daerah sekitar yang berdekatan dengan Kota Semarang. Jumlah pengunjung di Kebun Binatang mengalami peningkatan yang pesat saat post test. Hal 
ini disebabkan karena saat pelaksanaan pengukuran sesudah intervensi bertepatan dengan libur panjang sekolah, sehingga banyak masyarakat yang datang dan berwisata bersama keluarga dan anakanaknya. Hal ini diharapkan semakin banyak pengunjung yang datang ke tempat wisata maka semakin banyak yang membaca isi pesan poster sehingga meningkatkan kesadaran pengunjung membuang sampah pada tempatnya yang membuat pemanfaatan tempat sampah menjadi lebih baik.

Pendidikan kesehatan melalui media promosi kesehatan merupakan suatu proses belajar untuk meningkatkan pengetahuan, kesadaran dan praktik seseorang dalam waktu relatif singkat. Selain itu media pendidikan kesehatan merupakan upaya persuasi yang berpengaruh terhadap kebiasaan, sikap dan pengetahuan yang berkaitan dengan kesehatan perseorangan atau masyarakat. ${ }^{(11)}$ Sesuai dengan teori perilaku Lawrence Green yang menjelaskan bahwa perilaku sehat seseorang dipengaruhi oleh faktor enabling yaitu ketersediaan media kesehatan dan sarana tempat sampah yang menarik, sehingga menimbulkan kesadaran masyarakat untuk memanfaatkan tempat sampah dan akan memberikan dampak positif terhadap peningkatan status kesehatan seseorang. ${ }^{(12)}$ Hal ini sesuai dengan penelitian yang terdahulu yang menyatakan bahwa peningkatan perilaku konservasi dipengaruhi oleh fasilitas tempat sampah yang disediakan di tempat umum. $^{(13)}$ Tempat sampah pun sebaiknya dikategorikan berdasarkan jenis sampahnya, misal organik dan non organik. ${ }^{(14)}$ Semakin baiknya pengelolaan sampah, maka secara tidak langsung turut mengedukasi pengunjung mengenai pentingnya menjaga lingkungan. Manfaat secara umum dan material dari pengelolaan sampah yang baik selain peningkatan jumlah pengunjung dan pendapatan daerah, yaitu terwujudnya kondisi lingkungan tempat wisata yang tidak berisiko kesehatan bagi seluruh pengunjung. ${ }^{(15)}$

\section{SIMPULAN}

Terdapat pengaruh intervensi poster tentang anjuran buang sampah pada tempatnya terhadap peningkatan volume sampah di tempat sampah yang disediakan di area tempat wisata. Demikian juga penilaian kualitas tempat sampah yang memenuhi syarat sanitasi menjadi meningkat signifikan setelah diberikan intervensi. Pemberian intervensi poster anjuran pembuangan sampah membuat pengunjung mau membuang sampah pada tempatnya, dibandingkan dengan tempat wisata yang tidak diberikan intervensi. Pengunjung berkeinginan untuk memanfaatkan tempat sampah yang telah 
disediakan dengan kualitas baik dan menarik dibandingkan dengan yang tidak. Penelitian menyarankan kepada pihak pengelola wisata agar melakukan perbaikan sarana dan prasarana terutama dalam hal menjaga kebersihan di area tempat wisata, sehingga menambah daya tarik, keamanan dan kenyamanan pengunjung. Pentingnya meningkatkan kerjasama dengan semua pihak terkait dalam rangka menarik wisatawan terutama dalam menjaga kebersihan, keindahan dan kesehatan tempat wisata.

\section{KEPUSTAKAAN}

1. Basiya R, Rozak HA. Kualitas Dayatarik Wisata, Kepuasan dan Niat Kunjungan Kembali Wisatawan Mancanegara di Jawa Tengah. Dinamika Kepariwisataan. 2012;11(2):1-12.

2. Budi AS, Pahlawan I. Peran ASEAN Tourism Forum dalam Meningkatkan Kunjungan Wisatawan Asing di Indonesia (2009-2013). JOM Fisip. 2016;3(2):1-15.

3. Himawan H. E-Tourism: Antara Konsep dan Implementasi dalam Mendukung Industri Pariwisata Indonesia. Seminar Nasional Informatika. 2009;1(5):214-21.

4. Baker DMA. Tourism and the Health Effects of Infectious Diseases: Are There Potential Risks for Tourists?

International Journal of Safety and Security in Tourism/Hospitality. 2015;1(12):1-17.

5. Vilkman K, Pakkanen SH, Laaveri T, Siikamaki H, Kantele A. Travelers' Health Problems and Behavior: Prospective Study with Post-travel Follow-up. BMC Infectious Diseases. 2016;16(328):114.

6. Levinanda SS. Analisis FaktorFaktor yang Mempengaruhi Jumlah Kunjungan di Tempat Wisata Masjid Agung Jawa Tengah [skripsi]. Semarang: Fakultas Ekonomi dan Bisnis Universitas Diponegoro Semarang; 2015.

7. Novalisa E, Paturusi SA, Prasiasa DPO. Implementasi Kebijakan Pembangunan Pariwisata Kabupaten Katingan, Provinsi Kalimantan Tengah. JUMPA;4(1):151-167.

8. Nashriyah. Strategi Pemasaran Pariwisata Dinas Pariwisata dan Kebudayaan Kota Semarang (Tahun 2006-2007) [skripsi]. Surakarta: Fakultas Sastra dan Seni Rupa Universitas Sebelas Maret; 2008.

9. Direktorat Promosi Kesehatan dan Pemberdayaan Masyarakat Kementerian Kesehatan RI. Kategori Media: Poster [Internet]. 2019. Diakses di: 
http://promkes.kemkes.go.id/categor

$\mathrm{y} /$ poster/1

10. Wijaya IMW, Trihadiningrum Y. Strategi Penanganan Sampah di Tempat Wisata Eks Pelabuhan Buleleng, Bali [tesis]. Surabaya: Fakultas Teknik Sipil Institut Teknologi Sepuluh November; 2018.

11. Notoadmodjo S. Promosi Kesehatan dan Ilmu Perilaku. Jakarta: Rineka Cipta; 2012.

12. Green L, Kreuter M. Health Program Planning: An Educational and Ecological Approach. 4th ed. New York: McGraw-Hill; 2005.

13. Glanz K, Rimer BK, Viswanath K. Health Behavior and Health
Education: Theory, Research and Practice. 4th ed. San Francisco: Jossey-Bass; 2008.

14. Suarinastuti IA, Mahgangga IGAO. Pengelolaan Sampah di Daya Tarik Wisata Wanara Mana/Monkey Forest, Desa Padangtegal, Ubud. Jurnal Destinasi Pariwisata. 2016;4(2):25-29.

15. Hadiyanto DN, Zunariyah $\mathrm{S}$. Pengembangan Pariwisata Berwawasan Lingkungan (Studi Kasus Pengelolaan Sampah di Taman Satwa Taru Jurug Surakarta). Journal of Development and Social Change. 2018;1(1):53-64. 